\title{
REQUESTS AND POLITENESS IN VIETNAMESE AS A NATIVE LANGUAGE
}

\author{
Thi Thuy Minh Nguyen and Gia Anh Le Ho
}

\begin{abstract}
This study examines requests in Vietnamese, a much under-researched language, with a view to expanding the range of languages under inquiry. Open role-plays in six scenarios with differing social power and perceived imposition levels were used to elicit requests from nine Vietnamese native speakers. Data were analyzed with reference to the categorization of Blum-Kulka, House and Kasper (1989) for level of directness, choice of request strategy and use of modification.

The findings suggested that unlike requests in some European languages reported in the literature, requests in Vietnamese as a native language were realized predominantly by means of imperatives in equal power situations and query preparatories in low-to-high power situations, regardless of imposition levels. Requests were modified preferably by means of supportive moves such as steers and grounders, and lexical means such as address terms, honorifics, modal particles, and appealers. These findings are discussed with implications for cross-cultural communication and the teaching and learning of Vietnamese as a second language.
\end{abstract}

Keywords: Requests; Vietnamese; Politeness; Cross-cultural communication; Pragmatic strategies.

\section{Requests across cultures}

A request is a directive act performed to get the hearer to do something that is to the speaker's benefit and at the cost of the hearer. From the speaker's point of view, the hearer is able to do this act but it is not obvious that the hearer will do it in the normal course of events or of the hearer's own accord (Searle 1969). Requests have been the most researched speech act to date in cross-cultural, variational and interlanguage pragmatics (e.g. recently by Barron 2008; Byon 2006; Felix-Brasdefer 2007; Ogiermann 2009; Rue and Zhang 2008; Shively 2011; Upadhyay 2003; Woodfield 2008; Yu 2011) as well as in Conversation Analysis research (e.g. Al-Gahtani and Röver 2012; Taleghani-Nikazm 2005; 2006; Taleghani-Nikazm and Huth 2010). Among the pioneer studies on requests was Blum-Kulka and Olshtain's (1984) Cross-cultural Speech Act Realization Project (CCSARP). It aimed to provide a typology of realization strategies for requests in eight languages or varieties: Australian English, American English, British English, Canadian French, Danish, German, Hebrew, and Russian. This 
typology has been adopted in many later studies on requests (e.g. recently by Biesenbach-Lucas 2007; Chen 2006; Cohen and Shively 2007; Felix-Brasdefer 2007; Hendriks 2008; Octu and Zeyrek 2006; 2008; Ogiermann 2009; Schauer 2007; 2008; 2009; Shively 2011; Woodfield 2008; Yu 2011), making the CCSARP the most influential research study on this speech act to date.

The findings of the CCSARP have suggested that requests pose a threat to the hearer's negative face, i.e. the freedom of action and freedom from imposition (Brown and Levinson 1987). Therefore, the speaker has to employ appropriate linguistic means in order to minimize the degree of imposition that his or her requests may impinge on the hearer and protect the hearer's negative face. One way in which the speaker can minimize the imposition is by selecting an indirect strategy instead of a direct one (Blum-Kulka and Olshtain 1984). This is because indirectness implies tentativeness on the part of the speaker and optionality for the hearer (Leech 1983: 108). The speaker may also use syntactic modification such as negative or modal structures as distancing elements and hedging devices (Blum-Kulka and Olshtain 1984).

In a later study on native speakers' perceptions of politeness and indirectness in English and Hebrew, Blum-Kulka (1987) further pointed out that conventional indirectness is preferred over non-conventional indirectness (i.e. strong or mild hints) in requests in these languages. According to this study, politeness refers to the balance between two needs: Pragmatic clarity and avoidance of coerciveness. This balance is achieved only in the case of conventional indirectness but not in the case of nonconventional indirectness or directness. Preference for either pragmatic clarity or noncoerciveness will result in a decrease in politeness. Therefore, directness is often equated to impoliteness because it shows a lack of consideration for face. At the same time, nonconventional indirectness also implies impoliteness because it lacks pragmatic clarity. Many other empirical studies on requests in English have supported the findings of Blum-Kulka (1987), documenting that native speakers prefer conventional indirectness, particularly the query preparatory strategy while dispreferring directness in requests (e.g. Barron 2008; Billmyer and Varghese 2000; Hendriks 2008; House and Kasper 1987; Octu and Zeyrek 2008; Ogiermann 2009; Trosborg 1995; Woodfield 2008).

However, findings from research on other languages do not necessarily concord with the claim that conventionally indirect request strategies represent the highest degree of politeness (Byon 2006; Hassall 1999; Lee-Wong 1994; Matsumoto 1988; Ogiermann 2009; Rue and Zhang 2008; Upadhyay 2003; Vu 1997, 1999; Wierzbicka 1985; Yu 2011). Disagreeing with Searle (1975: 64) who claims that "[i]n directives, politeness is the chief motivation for indirectness", Wierzbicka (1985) maintains that this rule applies only to the English language and the Anglo-Saxon cultures. Ogiermann (2009) argues that some cultures prefer pragmatic clarity, often associating directness with honesty while interpreting indirectness as increasing the imposition on the hearer. This is because indirect strategies, particularly off-record requests, not only increase the interpretive demands on the hearer but also put the hearer in a position where they have to take the initiative to offer what the speaker is too reluctant to ask for. Therefore, more than often, indirectness may lead to communicative failure in those cultures. Studies on Russian requests indicate that unlike in English, imperative constructions are frequently used as a request realization strategy in Russian (Berger 1997; Betsch; 2003; Brehmer 2000; Larina 2003, all cited in Ogiermann 2009; Mills 1992; Ogiermann 2009). Similarly, studies on Polish requests show that imperatives can serve as polite requests 
especially when accompanied by mitigating devices such as intonation, the use of appropriate address forms, personal pronouns or modal particles (Lubecka 2000; Marcjanik 1997, all cited in Ogiermann 2009; Wierzbicka 1985).

Research on requests in Asian languages, such as Bahasa Indonesia, Korean, Nepali, Mandarin Chinese and Vietnamese has also challenged the claimed direct link between indirectness and politeness (e.g. Byon 2006; Hassall 1999; Lee-Wong 1994; Rue and Zhang 2008; Upadhyay 2003; Vu 1997; 1999; Yu 2011). For example, although conventionally indirect requests constitute the most frequently used realization strategies in Bahasa Indonesia (51\%), direct requests also make up a large proportion in this language (42.7\%) (Hassall 1999). Similarly, politeness in Korean requests can be expressed by means of direct strategies coupled with honorifics (Byon 2006). Conventional indirectness, on the other hand, is not significantly correlated with politeness in this language ( $\mathrm{Yu}$ 2011). The most frequently used form of requests in Nepali is the basic imperative construction and politeness can be conveyed by means of honorifics rather than by changing the directness level of sentences (Upadhyay 2003). Speakers of Mandarin Chinese also demonstrate an overwhelming preference for baldon record strategies as they tend to associate directness with sincerity while regarding conventionally indirect requests as inappropriate (Lee-Wong 1994; Rue and Zhang 2008). Generally, these findings do not endorse the direct relationship between politeness and linguistic indirectness, suggesting that this relationship is interpreted differently across cultures.

To date, speech acts in general and requests in particular in Vietnamese have been under-represented in pragmatics literature. Among the few available studies, Vu $(1997,1999)$ has offered a valuable insight into requests and politeness in Vietnamese. She collected naturally occurring requests by a group of Vietnamese native speakers as they were communicating in various social contexts. Her studies show that Vietnamese speakers prefer a high level of directness in making requests and rely more considerably on supportive elements with politeness effects rather than on indirectness for expressing politeness. Indirectness is also considered a politeness device; however, it does not rank as high as mitigated directness on the politeness continuum.

Overall, despite a growing interest in requests in the last few decades, earlier studies have focused on a fairly limited range of languages, thus inadequately shedding light on our understanding of how this speech act is manifested in various contexts of cultures. Most of the existing studies focus on a European language and only a relatively small number of studies investigate an Asian language. Therefore, it is important to further this line of research in order to understand how requests are performed across a wider range of languages, and hence to what extent strategies for performing requests are common across languages. Our study sets out to investigate the politeness strategies that a group of Vietnamese native speakers employ when requesting in everyday situations. By looking at this under-researched language, we aim to expand the range of languages under inquiry and contribute to furthering our knowledge of politeness phenomena in a wider variety of discourse communities. Another purpose in conducting this study is to inform cross-cultural communication between Vietnamese people and speakers of other languages as well as the teaching of Vietnamese as a heritage or second language. 


\section{Politeness in modern Vietnamese}

Since one of the aims of our paper is to examine politeness in Vietnamese requests, particularly whether the claimed link between indirectness and politeness by Brown and Levinson $(1978,1987)$ is supported by Vietnamese data, in this section we will first recapitulate the key concepts of Brown and Levinson's theory. Within the broader critiques of their theory, we will then review the extent to which Vietnamese politeness can be explained within their framework, particulary in relation to their conceptualization of face, negative politeness and their face-saving view of politeness.

Fundamental to Brown and Levinson's works are the concept of face which they define as public self-image and the two accompanying types of face wants, namely positive (i.e. desire to be accepted) and negative face (i.e. desire to be free from imposition), which, in their view, operate pan-culturally. Associated with these two types of face are positive and negative politeness strategies. Positive politeness is analogous with directness, including verbal strategies such as expressions of solidarity, informality and familiarity while negative politeness is equated to indirectness, comprising of expressions of restraint, formality and distancing. Between the two, negative politeness is considered more face redressive. A speaker decides between positive and negative politeness strategies when performing a speech act by considering the social and contextual variables involved. These variables include the social distance and relative power between the speaker and the hearer, and the degree of imposition of the given speech act as perceived within the given culture. As such, politeness is viewed as a tool for saving face.

Brown and Levinson's claim for politeness universals, however, has been challenged by the amounting evidence from non-Western politeness research. First, it has been shown that the act of face-saving in some cultures is not necessarily to do with satisfying an individual's psychological wants as asserted by Brown and Levinson. Mao (1994), for example, indicates that individualistic and self-oriented face is not characteristic of the Chinese culture. Rather, Chinese face emphasizes "the harmony of individual conduct with the views and judgement of the community" (Mao 1994: 460). In other words, face is related to social expectations and must be endorsed by the community; therefore, politeness is the conformity to these expected norms rather than attending to individual face wants (also see $\mathrm{Gu}$ 1990). Likewise, Wierzbicka (1985) argues that given the preference for involvement and sincerity over personal distance in Polish culture, negative face seems to be of little importance and does not adequately account for verbal interaction by Polish speakers. Face-saving may not also be the main driving factor that explains an individual's social behaviour in cultures where emphasis is placed more on marking social standing in relation to others in the community (Ide 1989; Matsumoto 1988). Based on her study of the honorific system in Japanese, Ide (1989) has shown that politeness is achieved not so much on the basis of volitional use of verbal strategies as on discernment (i.e. finding one's place) in this culture (also see Hill et al. 1986). More recent critics have challenged Brown and Levinson's conceptualization of face as an individual phenomenon and argued that face should be reframed within a relational and interactional framework within which face is seen as being interactionally achieved in relationships with others (see Arundale 2006).

When it comes to explaining Vietnamese politeness, Brown and Levinson's notions of face as an individualistic, self-oriented image and its concomitant negative face's claim to personal space also appear to hardly apply (N. Pham 2008). This is 
because Vietnamese politeness behavior tends to be group-oriented rather than selforiented and consequently negative face wants seem to play a negligible role (Vu 1997). Traditionally, the two key elements that underlie the notion of politeness and drive interactants' behavior in the Vietnamese culture include lê ('rules of propriety', 'rites', 'morals', 'proper conducts') and tình cảm ('sentiments') (Chew 2011). Lế is rooted in Confucian ideology and values, which deeply influence the cultural life of Vietnamese people, reflecting their emphasis on social indexing and serving to preserve relational and social order. In its essence, lê̂ involves lê̂ phép (i.e. 'respectfulness' or showing respect to people of higher power) and đúng muc (i.e. 'propriety' or showing proper respect to people of equal and lower power) (Vu 1997, 1999). From a young age, Vietnamese children are taught basic moral lessons such as tiên hoc lễ, hậu học văn (literally translated as 'first study lế; later study knowledge' or 'one needs to acquire the rules of lê̂ before acquiring academic/ scholarly knowledge') (N. Pham 2008). In interpersonal communication the Vietnamese must act in compliance with such social rules as biết trên biết duoơi (literally translated as 'knowing above, knowing below' or 'one must know one's social standing in relation to others'), trên ra trên dưới ra duới (literally translated as 'above has to be above; beneath has to be beneath' or 'one has to act according to one's social standing in relation to others), and kính trên nhương dưới (literally translated as 'respect the superior; yield to the subordinate', or 'show respect to the superior; show proper respect to the subordinate') (B. Pham 1999; Vu 1997). Apparently, in the Vietnamese culture one's social behavior is guided by how one positions himself or herself in social relationships. The second component of Vietnamese politeness, tình cảm, is manifested in such behaviors as 'care', 'intimacy', 'bond', and 'mutual help' (see Tran 1995, 2001), serving to maintain social harmony (Chew 2011). The Vietnamese promote lối sống tình cảm ('a sentiment way of life') and highly value tình làng nghĩa xóm (translated as 'love among people in a community') (Tran 1995, 2001). Their everyday courses of action and lifestyle are based on this value, which is evident in their proverb một trăm cái lý không bằng một tí cái tình (literally translated as 'a hundred rational thought does not weigh as much as one sentimental thought' or 'one should put compassion above logical thinking'). L $\tilde{\hat{e}}$, working alongside tình cảm, shapes the notion of face in the Vietnamese culture as social face, or to quote Mao (1994: 453), as "a public image that is on loan to individuals from society" rather than "a private or an internalized property" belonging to an individual as asserted by Brown and Levinson. Lễ also necessarily sets itself apart from 'giving deference' (belonging to the superstrategy of negative politeness in Brown and Levinson's model) since it underscores hierarchical social structure rather than an individual's desire for freedom of will and autonomy (a behavior that is of least importance in a culture that favors involvement and interdependence such as Vietnam) (see Matsumoto 1988 for a similar discussion).

Based on her investigation of politeness perceptions by Vietnamese speakers, $\mathrm{Vu}$ (1997) also points out that Brown and Levinson's face-saving view of politeness does not capture all the aspects of Vietnamese politeness. More specifically, she has found that when asked what is meant by politeness in speech, Vietnamese speakers identify four major behaviors, namely lê̂ phép ('respectfulness'), đúng mục ('propriety'), khéo léo ('tact/ artful speech') and tế nhị ('delicacy/ subtlety'). According to Vu, this shows that Vietnamese verbal interaction necessarily incorporates two important types of politeness, including 'respectful politeness' (lịch sụ lễ độ) and 'strategic politeness' 
(lịch sư chiến lược) in her terms. While the former serves to index social relationships, showing respect to status and solidarity, the latter is bound within specific speech events, serving immediate communicative goals and intents. Linguistic devices that help to convey the former type of politeness, according to $\mathrm{Vu}$, comprise of address terms using fictive kinship terms, honorifics or lexical means with a similar function. Speakers make these linguistic choices to display lễ phép/ đúng mục to their interlocutors while keeping distance vs. solidarity in conformity with the nature of the given speaker-hearer relationship. In comparison, linguistic means that display khéo léo/ tế nhị (i.e. 'strategic politeness') help to minimize the disadvantages and maximize the advantages of the situation so that one can achieve their communicative goal. These means may include such verbal strategies as indirectness and lexical items with mitigation function. $\mathrm{Vu}$ claims that due to a strong emphasis on the conformity of individuals' behavior to social expectations, 'respectfulness' politeness seems more prominent in Vietnamese social interaction than 'strategic' politeness. She also argues that while Brown and Levinson's model can describe the 'strategic' dimension of Vietnamese politeness, 'respectful politeness' is not identified with their politeness strategies:

$[R]$ espectfulness politeness (...) is clearly differentiated from Brown and Levinson's negative or positive strategies in terms of its functions: respectfulness politeness is behavior in conformity to the norms and conventions of society, and it does not necessarily entail individual strategies aimed at certain communicative goals (p. 88).

An example is the address term usage. According to Brown and Levinson, a speaker can make choice of address terms either to mark group identity (e.g. mate, buddy, brother, sister) (1978: 112-113) or to 'give deference' (e.g. Sir) to the hearer (1978: 187-189). That is, in Brown and Levinson's model, address terms are only strategically used to attend to the hearer's positive or negative face wants, based on the speaker's calculation of cost to the hearer; in other words, the usage is merely influenced by the speaker's intentions. In contrast, in the Vietnamese language address terms are an indispensable index of social relationships and expresses respect for and conformity to power and the social hierarchy. Their usage is constrained by the speaker's social role and obligations rather than by his or her intention. This is evidenced by that a 'no-naming' style (nói trống không) could severly violate social norms, especially when one communicates with his or her superiors in the formal context. Vu concludes that the co-existence of 'respectful politeness' and 'strategic politeness' in Vietnamese culture "attest[s] to the hypothesis suggested by Hill et al. (1986) on the existence of discernment and volition" (p. 331) (also see Ide 1989 for a similar discussion) and that rather than based only on a 'strategic' view of politeness, there is a need to consider both 'normative' and 'strategic' aspects when explaining how politeness operates in the Vietnamese culture.

\section{The study}

\subsection{Participants}

Nine native speakers of Vietnamese who responded to the researchers' advertisement for recruitment of research participants were invited to participate in this study. They were full time English language major students of a university in Hanoi where the second author once taught them English. Eight of them were female and one was male, 
whose ages ranged between 21 and 22. They were originally from various parts in Northern Vietnam.

\subsection{Data collection}

Six role-play scenarios were designed to elicit requests (see Appendices A and B) and the informants' performance was audio recorded. Some of the scenarios were adapted from Blum-Kulka and Olshtain (1984) and Hassall (2003). The role-play was selected because it allows for impromptu speech production in conversational sequences, thus sharing a number of similarities with natural speech production (Kasper 2008; Kasper and Rose 2002). On the other hand, unlike naturally occurring discourse, it allows us to observe how context factors such as power, distance and imposition (see Brown and Levinson 1987) affect the speaker's choice of pragmatic strategies. Its other strength is that it can yield a large corpus of data in a relatively short time. We acknowledge, however, that role-plays are fundamentally different activities from natural interaction, among others because role-plays are pretence without consequences for the participants. However, Okada (2010) argues that in role-plays participants draw on their interactional competencies by default. This justifies the use of role-plays in teaching/training and testing, and cautious use in research.

The six scenarios varied in the relative power between the speaker and the hearer but not in the social distance between them. They include: (1) borrowing a computer from a friend, (2) borrowing lecture notes from a classmate, (3) asking a roommate to return a book to the library, (4) asking a teacher to write a letter of recommendation, (5) asking a teacher for a deadline extension, and (6) asking a supervisor to change the date of an upcoming meeting. Scenarios 1 through 3 described an equal power relationship (request directed at a friend), while the relationship described in Scenarios 4 through 6 is characteristic of an unequal power (request directed at a lecturer/ supervisor). The social distance, however, was kept constant: All the scenarios described a close relationship between the speaker and the hearer.

In order to avoid the researcher's subjectivity as far as possible, before the role play took place the scenarios were given for the participants to rate the degree of imposition exerted on the hearer, using a Likert 5-point scale. Results showed that the degree of imposition was rated 'low' in Scenarios 1 (Computer) and 2 (Lecture Notes) (means falling below 3.0). This was rated 'medium' in Scenarios 3 (Library), 4 (Letter of Reference), 5 (Assignment) and 6 (Meeting) (means between 3.0 and 3.5) (see Table $1)$.

Before being used for the present study, the role-plays were piloted with another group of native speakers of Vietnamese. Adjustments were then made to the instruction and scenario descriptions to enhance their comprehensibility. Also, because participants may find it difficult to perform in a role-play if the tasks are not realistic (see Bonikowska 1988; Kasper 2008), before the role-play took place, the participants were asked to rate the extent to which they felt they were able to imagine themselves in each scenario, using a Likert 5-point scale. Results indicated that the informants scored quite high on all scenarios (means varying from 4.4 to 5.0), suggesting that they were familiar enough with the scenarios. Based on this result, all scenarios were kept for data collection. Each informant then role-played in Vietnamese for approximately one hour 
with the second author. As a result, 54 role-play conversations including 164 requests were yielded.

Table 1: The role-play scenarios

\begin{tabular}{llll}
\hline Scenario & Social distance & Relative power & $\begin{array}{l}\text { Degree of } \\
\text { imposition }\end{array}$ \\
\hline 1. Computer & Close & Equal & Low \\
2. Lecture notes & Close & Equal & Low \\
3. Library & Close & Equal & Medium \\
4. Letter of reference & Close & Low to High & Medium \\
5. Assignment & Close & Low to High & Medium \\
6. Meeting & Close & Low to High & Medium \\
\hline
\end{tabular}

\subsection{Data analysis}

The role-play conversations were transcribed and data were then coded, using BlumKulka, House and Kasper's (1989) taxonomy with slight adaptations to cater for the specific features of politeness in Vietnamese (see section 2). Following this framework, requests were coded according to their (1) levels of directness, (2) strategy types, and (3) modifiers. The level of directness refers to the extent to which $S$ (speaker)'s intent is made transparent (see Blum-Kulka 1987). A strategy is a semantic formula by which the request is expressed (see Blum-Kulka et al. 1989, Takahashi 1996). Modifiers are illocutionary force mitigating devices and include both external and internal types. External modifiers are supportive moves that occur before or after the head act, whereas internal modifiers occur within the head act and form an integral part of it (Kasper 1981). The two authors coded the data independently and then cross-checked their coding until a full agreement was achieved.

\section{Findings}

\subsection{A typology of request strategies in Vietnamese}

The following types of request strategy types were identified in the data. Note that the participants often combined different strategies in a single turn. In the following examples the strategy under discussion is underlined. ' $\mathrm{P}$ ' refers to the participant and ' $\mathrm{I}$ ' refers to the interlocutor.

DIRECT STRATEGIES

a. Imperatives: Mood derivable structures in full or elliptical form.

(1) Scenario 3

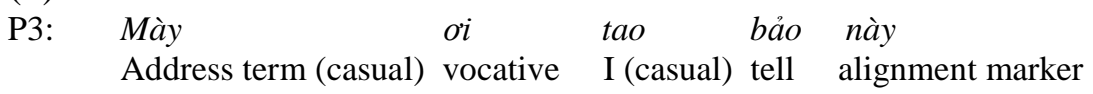

Hey, let me tell you this

Hôm nay tao không có tiết ỏ truờng.

Today I (casual) not have class at school 
I don't have a class today.

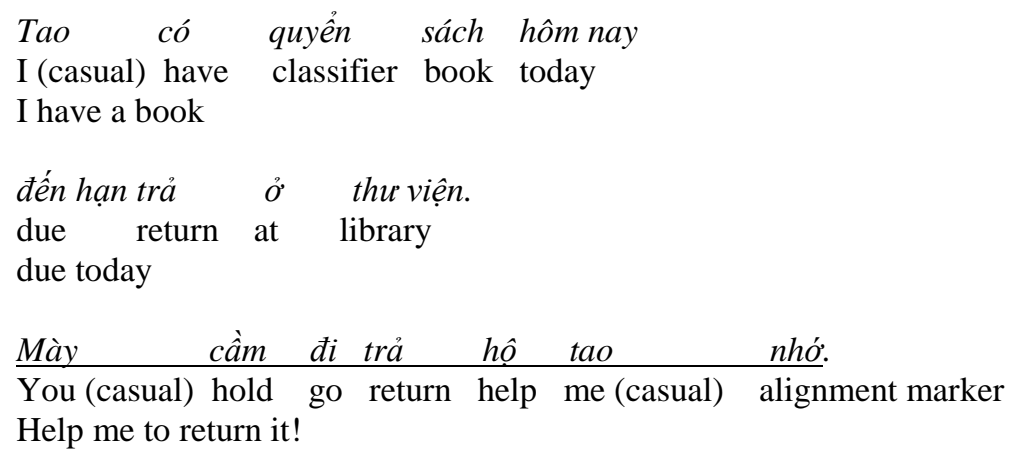

b. Performative: Containing performative verbs that denote the request such as đề $n g h i$ [request], bảo [tell], nhò [ask for help], xin [beg], etc. with or without hedges (e.g. muốn [would like/ want]).

\section{(2) Scenario 5}

P8: Cô ơi hômnaylà đến ngày em nộp cho cô Teacher vocative today be due I (student) submit for teacher Today I am supposed to submit to you

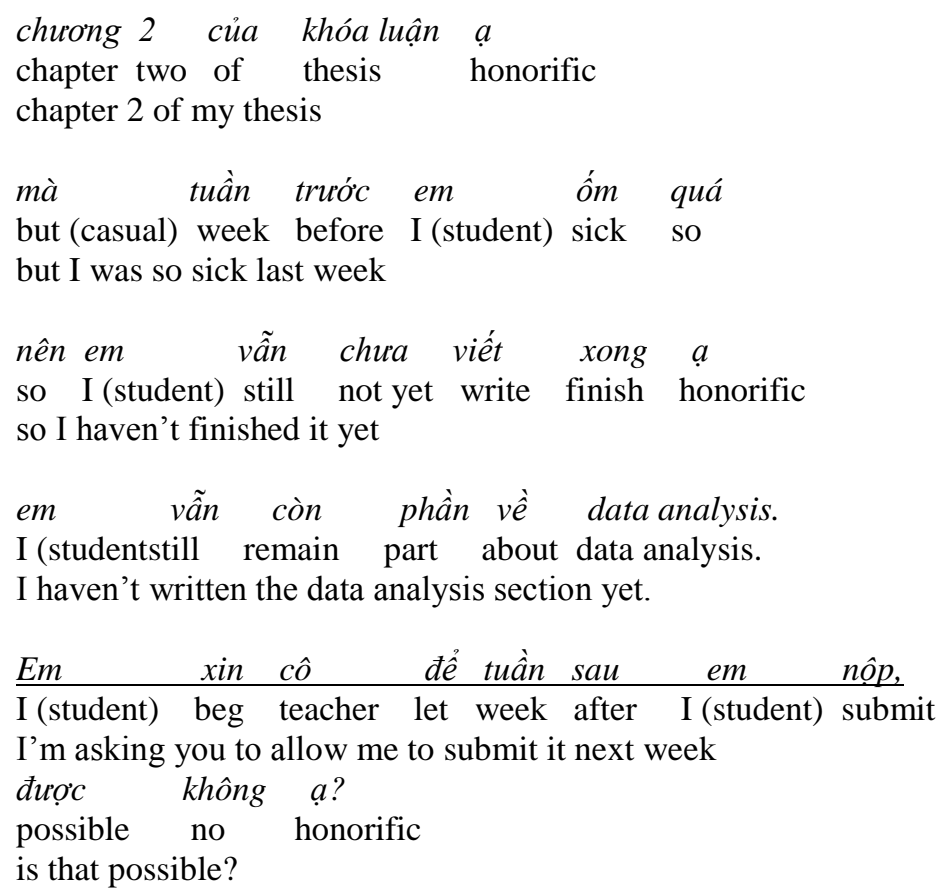

c. Obligation \& necessity: Containing verbs that denote obligation and necessity such as nên [should], cần (phải) [need to], phải [have to]. Note that this strategy was absent in the data.

d. Want statement: Containing verbs that denote S's needs, wishes and desires such as muốn [want], cần [need] phải [have to]. 
(3) Scenario 2

P9: Biết ngay mà

Know immediately stance marker

I know it

mọi lần toàn thấy ghi đầy đủ

every time always see write fully

you always take careful notes

thì tó mói murọn chú.

then I (intimate) stance marker borrow stance marker.

that's why I only borrow your notes.

Tó́ hỏi chúr

I (intimate) ask stance marker

That's the reason why I ask you

\begin{tabular}{llllll} 
tó & muốn & muoơn & vớ & của & bà. \\
\hline I (intimate) & want & borrow & notes & of & you (playful)
\end{tabular}

I want to borrow your notes.

\section{CONVENTIONALLY INDIRECT STRATEGIES}

e. Suggestory formula: Utterances beginning with Thế thì [So], Không thì or Hay là $[\mathrm{Or}]$ and pronounced in a rising intonation. Suggestions often come after an initial failure to get the hearer $(\mathrm{H})$ to perform the act.

(4) Scenario 1

P4: thế thì chuyển sang dùng điên thoai đi How about using telephone instead?

rồi tôi tặng cái thẻ điện thoại. then I (playful) give classifier card telephone

I will give you a telephone card.

f. Query preparatory: The speaker refers to the preparatory condition for the realization of a request, for example, the speaker checks the hearer's ability/ willingness to perform the act, or asks for permission to perform the act. Very often, the utterance takes the form of a question ${ }^{1}$.

(5) Scenario 4

P7: $\quad$ Cô ơi,

Teacher vocative

Teacher,

${ }^{1}$ Note that the Vietnamese language has the modal verb có thể, which denotes ability, possibility and permission (equivalent to can, could, may, might in English) but this verb is only optional in ability/ permission requests. Vietnamese ability/ permission requests are more often expressed via the structure “S + V ... được không?" [possible-no, is is ok ...?]. Có thể in this case only functions as a modifier. 
em chuẩn bị nộp cho

I (student) prepare apply for

I'm applying for

1 cái hoc bổng ấy a

one classifier scholarship affirmative marker honorific

a scholarship

mà rất cần sự giới thiệu của giáo viên

that very need introduction of teacher

I really need a recommendation letter from a teacher

$\begin{array}{lll}\text { trong truòng } & \hat{a} y & a . \\ \text { at school } & \text { affirmative marker } & \text { honorific } \\ \text { of our school. } & & \end{array}$

Mà cô đã dạy tiếng Anh

That teacher past marker teach English

And you have taught me English

được $2-3$ ki rồi ấy a.

for two three semester already affirmative marker honorific

for two or three semesters.

Em có thể nhò cô viết thu giới thiệu

I (student) can ask for help teacher write letter introduce

Can I ask you to write a letter of recommendation

giúp em đươc không a?

help me (student) possible no honorific?

for me please?

\section{NON-CONVENTIONALLY INDIRECT STRATEGIES}

g. Hints: The speaker's intent can be inferred thanks to his/ her reference to the precondition for the realization of the request (e.g. the hearer's availability) or to the reason for the request. Unlike a query preparatory, a hint is not conventionalized ${ }^{2}$.

(6) Scenario 6

I: Chào em. Ơ sao em tến sớm thế?

Hello you (student). Suprise marker why you (student) come early so?

Hello, why are you here so early?

P6: À. Cô ơ em dang chạy

Ah. Teacher vocative I (student) progressive marker run

${ }^{2}$ Note that an utterance can be coded as a 'hint' only when it occurs alone in an exchange (not together with another strategy type). Otherwise, it would be more suitably coded as a supportive move rather than the head act. 


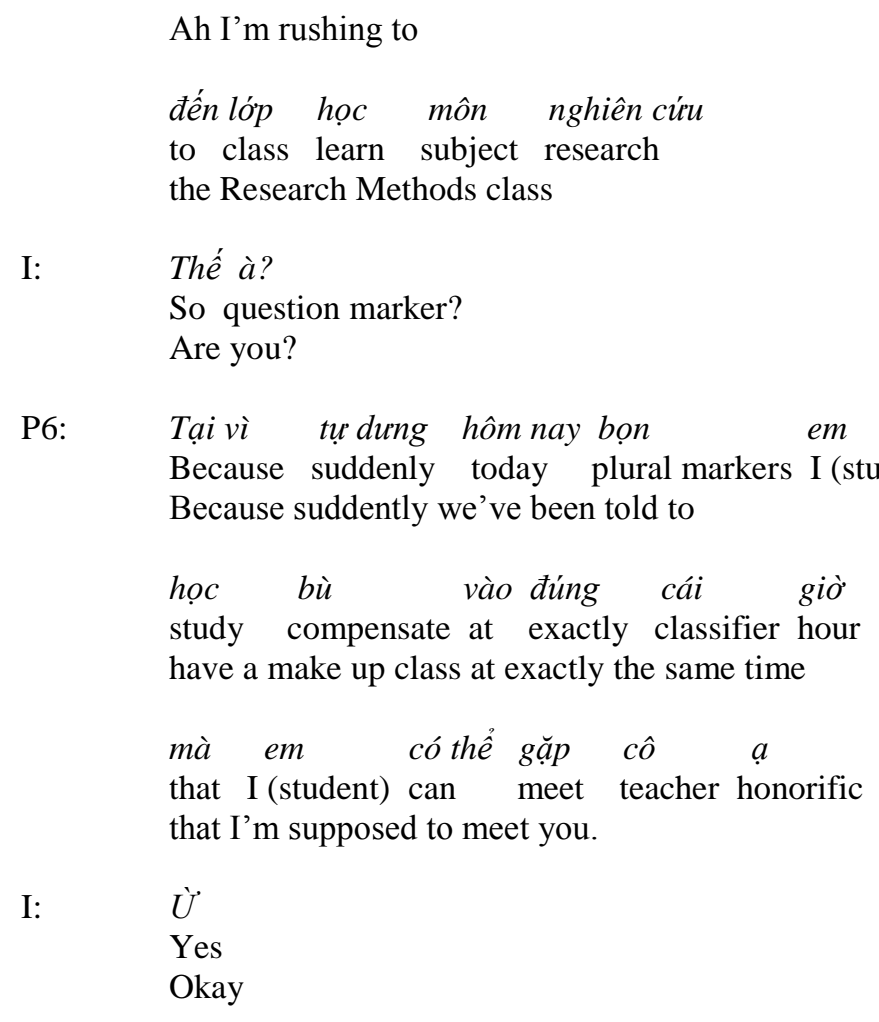

P6:

Cô oi $\quad c o ́$ lúc nào khác buổi chiều không?
Teacher vocative have time which other afternoon no?
Do you have any other time in the afternoon?

\subsection{Distribution of strategy types}

Results show that direct requests accounted for a large percentage (53\% or 87 out of 164 requests). Among direct strategies, imperatives were used most frequently $(33.5 \%$ or $55 / 164)$, followed by performatives $(11.6 \%$ or $19 / 164$ requests). Want statements made up of only $8 \%$ (13/164). No statements of obligation and necessity were found in the data. Conventionally indirect strategies were used $46.3 \%$ of the time $(76 / 164)$. The most frequently used indirect strategy was query prepartories $(26.8 \%$ or $44 / 164)$, followed by suggestory formulas $(19.5 \%$ or $32 / 164)$. Non-conventionally indirect requests were almost absent $(0.6 \%$ or $1 / 164)$ (see Table 2$)$.

An analysis of distribution of strategies according to situational variations indicates that the power difference between the speaker and the hearer affected the speaker's pragmatic choice $\left[\chi^{2}(5, \mathrm{~N}=164)=39.06, p<.001\right]$. In particular, the informants tended to prefer imperatives in equal power scenarios (49\%) (see example 1 above) whereas they liked to opt for query preparatories in low-to-high power scenarios (40\%) (example 5).

However, imposition levels did not affect the informants' strategy use $\left[\chi^{2}(5, \mathrm{~N}\right.$ $=164)=4.46, p>.05]$. This was probably because from the learners' point of view, the scenarios did not differ greatly in this aspect. Indeed, their scores on the degrees of imposition in six scenarios did not show much discrimination (ranging between 2.0 and $3.4)$. 
Table 2: Frequency of use of request strategies

\begin{tabular}{lll}
\hline Strategy & Raw counts & Percentage \\
\hline Direct & 87 & 53 \\
$\quad$ imperative & 55 & 33.5 \\
$\quad$ performative & 19 & 11.6 \\
$\quad$ obligation & 0 & 0 \\
$\quad$ want statement & 13 & 8 \\
Conventionally indirect & 76 & 46.3 \\
$\quad$ suggestion & 32 & 19.5 \\
$\quad$ query & 44 & 26.8 \\
Non-conventionally indirect & 1 & 0.6 \\
Total & 164 & 100 \\
\hline
\end{tabular}

\subsection{A typology of request modifiers in Vietnamese}

Data analysis indicates the following category of modifiers. Note that the participants often combined different types of modifiers in a single request. In the following examples the modifier type under discussion is underlined.

EXTERNAL MODIFIERS: Supportive moves that occur before or after the head act.

a. Steers: Phrases that are used to prepare the hearer for the request. The speaker may do so by checking if the hearer is available to perform the request. Steers are used to avoid being abrupt and inconsiderate.

(7) Scenario 1

P1: Linh oí, $\quad \begin{aligned} & \text { mày dang chát với ai đấy? } \\ & \text { Name vocative }\end{aligned}$

Linh, who are you chatting with?

I: À, tao đang chát với lại bạn trai tao. Ah I (casual) progressive marker chat with boyfriend me I'm chatting with my boyfriend.

P1: Thế à, quan trong không?

So question marker important no

Are you? Is it important?

I: $\quad$ Ò. Quan trong lắm.

Yes. Important very

Yes, it is.

Tại vì cũng lâu lắm rồi không nói chuyện với anh ấy.

Because also long very already no talk with him

Because I haven't talked to him for a while. 
b. Pre-sequences: The speaker announces that they are going to make a request or checks if the hearer is willing to hear the request.

(8) Scenario 4

$\mathrm{P} 4$

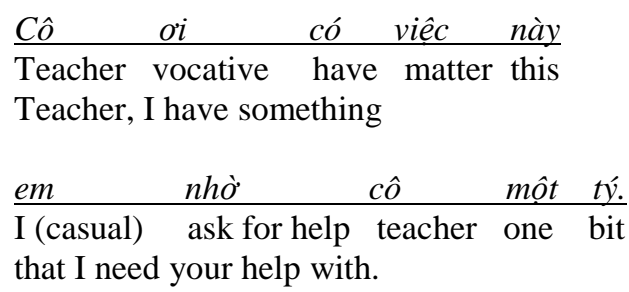

c. Grounders: Excuses, reasons or explanations that the speaker uses to justify their request and thus to appear reasonable.

(9) Scenario 5

P2:

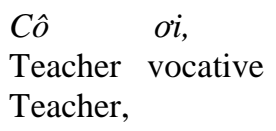

d. Disarmers: Utterances that the speaker uses to show their awareness of the pressure that the request may place on the hearer. The speaker might want to acknowledge the pressure and/ or apologize.

\section{(10) Scenario 5}

P3: $\quad$ Em thira cô

I (student) honorific teacher

Teacher

vì là thời tiết nó thay đổi

because weather it change

because of the weather change

cho nên đợt vù̀a rồi em ốm quá ạ.

so recently I (student) sick very honorific

I've been really sick recently.

Thế là em chura

So I (student) not yet

So I haven't 


em biết cô $\quad$ vấn rất là bân.
I (student) know teacher still very be busy
I know you are very busy
Nhung mà em chura xong dược
But I (student) not yet finish possible
But I haven't finished my chapter yet

e. Imposition minimizers: Utterances that the speaker uses to free the hearer from the imposition of the request.

\section{(11) Scenario 4}

P6:

Thế lúc nào mà cô thấy không bất tiên quá
So when that teacher see not inconvenient very
So when it's not too inconvenient to you
thì cô nhó giúp em cô nhá?
then teacher remember help me teacher alignment marker
please remember to help me!

f. Committers: The speaker may want to minimize the cost for the hearer by expressing their compromise with the hearer's conditions or offering to make it easier for the hearer to perform the act.

(12) Scenario 5

P9:

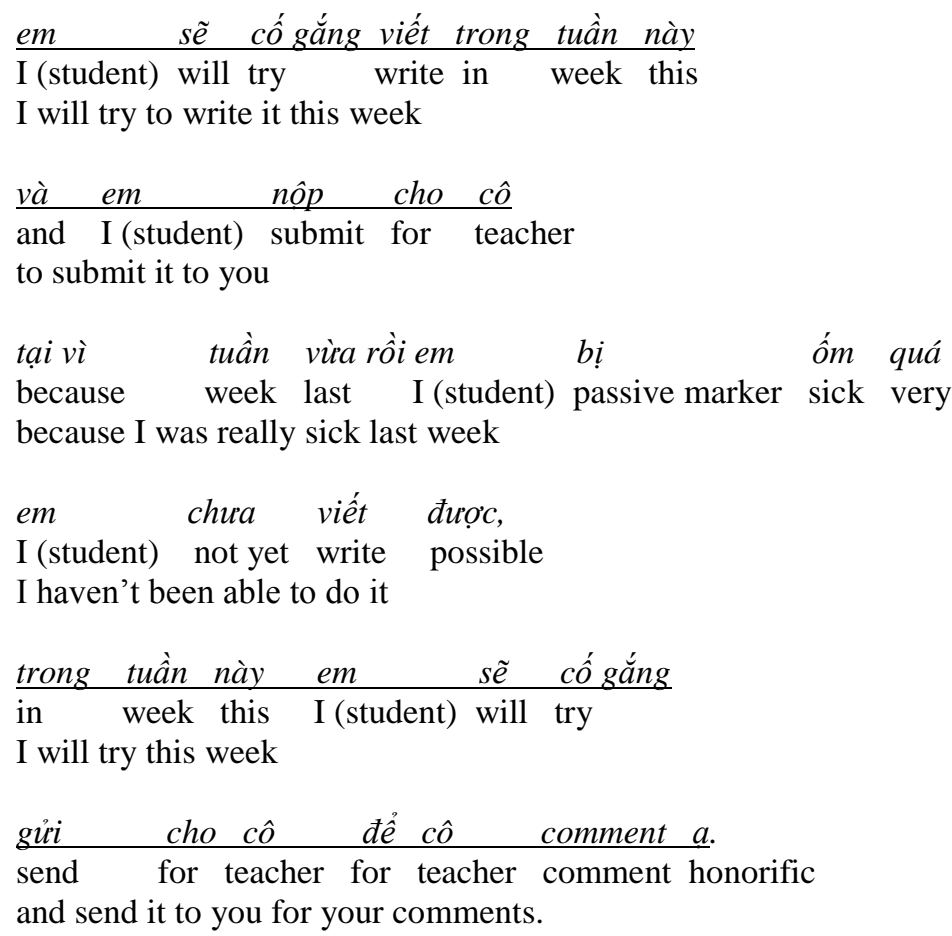

g. Understatement: The speaker may want to understate the request so as to convince the hearer of the minimal cost of the act. Understatements normally occur when the hearer shows hesitation to help. 


\section{(13) Scenario 1}

P2: Này Huyền cho tao muợn máy tính cái.

Attention seeker name let me (casual) borrow computer imperative marker Hey, Huyen, let me borrow your computer.
$O$
nhưng bây giờ tao
dang
dùng mà.

Suprise marker but now I (casual) progressive marker use stance marker But I'm using it now

P2: Tao chi viết 3 trang thôi.

I (casual) just write three pages only

I only need it to write just three pages.

Sau đấy mày dùng tiếp được không?

After that you (casual) use continue possible no

After that you can use it. Is that possible?

h. Offers of compensation: The speaker may also reduce the cost for the hearer by offering the hearer compensation or a reward.

\section{(14) Scenario 1}

P3: $\quad$ Thôi thì chịu khó giúp tó́.

So bear difficulty help me (intimate)

So take trouble to help me

$$
\begin{array}{llll}
C o ́ & g \grave{l} \quad \text { tó } & \text { se } g i u ́ p ~ c a ̂ u & \text { sau } \\
\text { Have what (intimate) } & \text { will help you (intimate) later } \\
\text { I will help you later }
\end{array}
$$

i. Sympathy seekers: The speaker may want to appeal for the hearer's sympathy so as to increase the chance of success of the request. This category is absent in Blum-Kulka et al. (1989) but has been added to fit data of this study.

\section{(15) Scenario 3}

P9: $\quad$ B4 thì chay ra thu viện cũng nhanh mà.

B4 (location) emphasis marker run to library also quick stance marker B4 is so close to the library

Hồ tó the tý
Help me (intimate) bit
Help me
để lâu thu viện nó... cô thu viện cồy
keep long library it classifier librarian her
If I don't return it, the librarian

lai tính tiền thêm

again count money more

will ask me to pay more fine

thì tớ chết mất 
then I (intimate) die lose

I will sure die

$\begin{array}{llll}\text { tó } & \text { dã } & \text { dể } & \text { lâu rồi } \\ \text { I (intimate) } & \text { past marker keep } & \text { long already } \\ \text { It's already overdue } & & & \end{array}$

j. Smoothers: The speaker may want to appeal for the hearer's willingness to perform the act by offering the hearer a compliment/ appreciation or emphasising the hearer's role.

(16) Scenario 1

$$
\begin{aligned}
& \text { P3: } \quad \text { Mày } \quad \text { oi } \\
& \text { You (casua) vocative } \\
& \text { Hey } \\
& \begin{array}{l}
\text { Mày là ban tốt của tao } \quad \text { mà. } \\
\text { you (casual) be friend good of me (casual) } \\
\text { You're my good friend. }
\end{array} \\
& \text { Đồng ý đi, giúp tao di. } \\
& \text { Agree imperative marker, help me (casual) imperative marker } \\
& \text { Agree to help me, okay? }
\end{aligned}
$$

k. Thanking: The speaker may want to increase the benefit for the hearer by expressing their gratitude to the hearer for the act, e.g. "Cảm on nhé!" (Thanks!) or "Em cảm on cô ạ" (Thank you, teacher!)

INTERNAL MODIFIERS: Occur within and form part of the head act

a. Address terms: Address terms in the Vietnamese language include kinship terms, titles, personal pronouns, and proper names occurring in alerters, subjects or other places in the utterances ( $\mathrm{Vu}$ 1997). Address terms are important in the Vietnamese language because a 'no-naming' style (i.e. "nói trống không") violates social norms, particularly when communicating with superiors and in formal contexts. Interlocutors make choices of address terms depending on the relative power and social distance between themselves and the wrong choice of address terms may threat H's face. This means politeness is determined not only by the use or non-use of address terms, but also by the appropriate choice in conformity to social norms and speaker-hearer role relationships (Vu, ibid: 170).

Note that Blum-Kulka et al. (1989) do not categorise address terms as request modifiers but since these linguistic features function as markers of 'respectful' politeness in Vietnamese, we classify them as a type of internal modifiers.

Our data show that $95 \%$ (156/ 164) of the head acts included address terms. Although the other 5\% (8/ 164) of head acts without address terms only occurred in equal power scenarios (i.e. Scenarios 1, 2 and 3), politeness was still maintained via the use of other modifier types. Our data also show that all the 
address terms were used appropriately across scenarios. For example, in status equal scenarios address terms were used to index solidarity and intimacy (e.g. $t o ̛$ ' - cậu; tao - mày; mình -bạn, see examples 1, 3, 13, 14 and 16 above). Some participants even chose seemingly formal address terms such as tôi - bà to display a playful tone, thus demonstrating an intimate relationship between them and their interlocutors. In lower-to-higher status scenarios the participants unanimously chose $\mathrm{em}$ to address themselves and $c \hat{o}$ to address their female teachers, emphasizing hierarchy, formal solidarity and respect (see examples 2, $5,6,8,9,10,11$ and 12 above). This behavior is expected in student-teacher role relationships in the Vietnamese culture.

It is our view that the frequency count of occurrence of address terms may not be as important as the analysis of whether they are used appropriately or not. Therefore, we decided not to include address terms when counting the number of internal modifiers in our data.

b. Honorifics: Particles, honorifics, and verbs that express respect to H, e.g. vâng, $d a$, $a$ [honorifics], làm on [do favour], xin [beg], cho [give], họ [help], etc. This category is absent in Blum-Kulka \& Olshtain (1984) but has been added to fit our data.

c. Downgraders: Adverbial modifiers that help $\mathrm{S}$ to downgrade the act, e.g. môt chút, một tý [one bit], etc.

d. Downtoner: Verbs and sentence modifiers that $\mathrm{S}$ uses to reduce the pressure his/ her request may place on $\mathrm{H}$ such as có lée, có thể, chắc là [perhaps, possibly, maybe/ may, probably), etc.

e. Appealers: Particles or phrases S uses to call for H's understanding and sympathy, e.g. nhé, với, đi, cái [alignment markers], được không? [possible no?] ${ }^{3}$ This category is absent in Blum-Kulka et al. (1989) but has been added to fit our data.

\subsection{Distribution of modifiers}

Results show that the informants modified their requests with a relatively high frequency (3.29 modifiers per request). They relied on external modifiers to soften their utterances for $60.6 \%$ of the time (see Table 3 ). In particular, they preferred grounders (37\% or $119 / 319)$, steers $(18 \%$ or $58 / 319)$, thanking ( $12 \%$ or $35 / 319)$, committers and understatements $(11 \%$ or $34 / 319)$. Other types of external modifiers such as disarmers (8/319), imposition minimizers (3/319) and compensations (8/319) were almost absent.

\footnotetext{
${ }^{3}$ Note that đươc không is coded as an appealer only when it is not part of the syntactic structure of the request but is an independent element that functions as an agreement seeker, such as in example 2 in the manuscript. If đươc không is compulsory for the syntactical structure of the sentence as in the case of ability/ permission requests, it is not coded as an appealer.
} 
Except for address terms which occurred in $95 \%$ of the head acts, the most frequently used types of internal modifiers were honorifics $(47.4 \%$ or $99 / 218)$ and appealers (i.e. modal particles) $(28.7 \%$ or $62 / 218)$. Downgraders (17.2\% or $43 / 218)$ and downtoners $(6.7 \%$ or $14 / 218)$ were employed far less often.

Table 3: Mean number of modifiers produced per request

\begin{tabular}{lllll}
\hline Types & Raw counts & Mean & SD & Percentage \\
\hline External modifiers & 319 & 2.00 & .36 & 60.6 \\
Internal modifiers & 218 & 1.29 & .27 & 39.4 \\
Total & 537 & 3.29 & .49 & 100 \\
\hline
\end{tabular}

\section{Discussion}

\subsection{Universality and culture-specificity in request strategy and modifications}

Similarly to previous studies (e.g. Byon 2006; Hassall 1999; Lee-Wong 1994; Matsumoto 1988; Ogiermann 2009; Rue and Zhang 2008; Upadhyay 2003; Vu 1997; 1999; Wierzbicka 1985), the findings of this study support the existence of universal strategies for making requests but indicates culture-specific differences in the preference for certain strategies. For example, although the Vietnamese speakers had all the strategies at their disposal, they tended to rely predominantly on imperatives and query preparatories for expressing their requests. Other strategies such as statements of obligation and necessity and hints were hardly used.

The analysis of request modification used by the Vietnamese participants highlighted some noteworthy culture-specific features. First, disarmers and imposition minimizers were scarcely used. Perhaps this can be explained by the lack of concern for personal space in the Vietnamese culture ${ }^{4}$ (Nguyen 2008, 2011). The Vietnamese

\footnotetext{
${ }^{4}$ One anonymous journal reviewer commented that the role-play data might have been affected by the prior social familiarity between the researchers and their subjects. In particular, the high level of directness and low incidence of disarmers as well as imposition minimizers shown in the data might simply reflect the lack of social distance between the speakers rather than the lack of concern for personal space in the Vietnamese culture. We would not necessarily agree with this interpretation, however, even if we assumed that the participants' acting might have been affected by their real-life roles. First, although the participants had been taught by the second author for one academic year, they were no longer in her class at the time of data collection as she had relocated to another institution. Their lack of continual contact may lower the degree of closeness between them. Second and more importantly, under the influence of Confucian values, the Vietnamese people are characterized by the tradition of tôn sur trong đạo (literally translated as 'respecting the teacher and morality'). The teacher is held in utmost respect in the Vietnamese culture and it is a moral obligation for Vietnamese students to closely observe this norm of behavior. As often seen in the classroom context, students address their teachers respectfully using titles and honorifics, for example Thua thầy/ thua cô (translated as 'Respectfully, Teacher'). Therefore, we would argue that it is due to such a high level of power asymmetry between students and teachers in the Vietnamese culture that hardly any degree of social familiarity between them can be interpreted as a lisence for the former to speak to the latter as if they were equal partners. Recalling that $\mathrm{Vu}(1997,1999)$ also reported a strikingly high level of directness in naturally occurring requests by Vietnamese speakers as they were interacting in various social scenrios (+ power, - power, + distance, - distance), we would argue that directness is not necessarily an indicator of a lack of social distance between the speakers.
} 
culture is characterized by a collective orientation which emphasizes involvement, interference, interdependence and a strong sense of familial duties (see Tran 1995, 2001). Therefore, in this culture the act of requesting may not necessarily be seen as 'imposing'. Indeed, these cultural characteristics are clearly reflected in the participants' use of sympathy seekers as a means of convincing their interlocutors to fulfil their requests. This finding emerges as particularly salient because sympathy seekers have not been reported in previous studies (e.g. Barron 2008; Hassall 2003; Hendriks 2008; Octu and Zeyrek; 2008; Ogiermann 2009; Shively 2011).

Another interesting observation is that Vietnamese requests are typically internally modified by lexical means such as address terms, honorifics and modal particles (see $\mathrm{Vu}$ 1997, 1999 for similar findings). This is different from English requests which are often mitigated by syntactic means (see Blum-Kulka and Olshtain 1984; Blum-Kulka et al. 1989; Hendriks 2008; Trosborg 1995). The reliance on lexical means by Vietnamese speakers is attributed to both linguistic and cultural features of this language. Linguistically, the Vietnamese language is based primarily on semantic rather than formal properties for expressing both grammatical and pragmatic meanings. Culturally, address terms indicate social roles and status in relation to other people, which is an important aspect of a collectivism-oriented society. Honorifics reflect the high value that the Vietnamese people place on modesty, humility and respect (T. Pham 1995). Modal particles that are alignment markers are an important means for solidarity building (Vu 1997, 1999). Indeed, Vu (1997, 1999) points out that these modifier types rank high on the politeness continuum in Vietnamese.

\subsection{Indirectness and politeness}

In pragmatic theories indirectness is often associated with politeness (e. g. Brown and Levinson 1987; Grice 1975; Leech 1983). This link is often claimed to be universal (Blum-Kulka and Olshtain 1984). Nonetheless, research on non-English languages has provided contrary evidence (e.g. Byon 2006; Hassall 1999; Lee-Wong 1994; Matsumoto 1988; Ogiermann 2009; Rue and Zhang 2008; Upadhyay 2003; Vu 1997; 1999; Wierzbicka 1985; Yu 2011). Findings from the present study add further evidence that perceptions of this link are coloured by cultural norms and expectations. Thus, the indirectness-politeness association must be interpreted from a language and culture specific perspective.

The participants of the present study demonstrated a strong preference for directness, particularly imperatives when making requests (see also requests in Chinese, Korean, Russian and Polish in Byon 2006; Hassall 1999; Lee-Wong 1994; Matsumoto 1988; Ogiermann 2009; Upadhyay 2003; Vu 1997; 1999; Wierzbicka 1985). These findings were congruent with those from $\mathrm{Vu}(1997,1999)$, suggesting that imperatives do not necessarily imply impoliteness in Vietnamese. Indeed, when asked, 76.7\% of the Vietnamese respondents in Vu's $(1997,1999)$ studies did not consider barely mitigated imperatives inappropriate while $64 \%$ deemed mitigated 'imperatives' to be polite.

The above findings may be explained by that Vietnamese verbal interaction tends to prefer 'involvement' and 'sincerity' over personal space. For example, Vu

Rather, it would be more plausible to link it to the lack of an individualistic orientation in the Vietnamese culture where perhaps personal space is the least important concern and in contrast values such as 'bond', 'intimacy', 'interdependence' and 'involvement' are more emphasized (see Tran 1995, 2001). 
(1999: 41) has pointed out that in Vietnamese an invitation that implies a high level of obligation such as 'Bà phải ở đây chơi đến tối đã' (literally translated as 'You must stay to be my guest til the end of the day') can be even more polite than one with a lower level of obligation such as 'Sao bà không ở đây chơi đến tối đã?' (literally translated as 'Why don't you stay to be my guest til the end of the day?') because the former expresses the speaker's care and sincerity to a greater extent than the latter.

The present study also found power effects on the participants' requesting behavior. That is direct requests were used more often in equal power relationships whereas indirect requests were used more often in lower-to-higher power scenarios. This difference seems to exemplify the two aspects of 'respectful politeness' ('lịch sự lễ độ') in Vietnamese: 'respectfulness' ('lễ phép') and 'propriety' ('đúng mực'). A speaker of Vietnamese has to make a choice between these two aspects depending on the relationship with their interlocutor. 'Respectfulness' is enacted to show respect to people of higher power. 'Propriety' is exercised to show proper respect to people of equal and lower power.

Related to this finding, however, there exist certain differences between the present study and $\mathrm{Vu}(1997,1999)$. That is the participants in this study used imperatives much less frequently than those in $\mathrm{Vu}(1997,1999)$ (cf. 33.5\% vs. 90\%), particularly in lower-to-higher power social relationships. Presumably, this could be explained by the differences in data collection methods and participants of the two studies. While this study employed role-plays, the other one collected naturally occurring data. The participants of this study were more homogenous in terms of age, gender and education background. They were all young people studying English. Their foreign language acquisition and exposure to another culture may have influenced their pragmatic behaviour. On the other hand, Vu's (ibid.) participants were more heterogeneous, hence being more representative of the Vietnamese population.

Overall, on the basis of the above discussion, it is apparent that pragmatic perceptions and performance are affected by not only inter-cultural but also intracultural (situational and individual) variability. Therefore, for effective communication an understanding of both pragmatic universals and pragmatic variability at different levels is equally important.

\section{Conclusion}

The present study offers some implications for cross-cultural communication between Vietnamese people and speakers of other languages as well as the teaching and learning of Vietnamese as a heritage and second/ foreign language. Unlike native speakers of some European languages such as English and German (see House and Kasper 1987), native speakers of Vietnamese tend to prefer a high level of directness in making requests and rely more considerably on supportive elements with politeness effects such as address terms, honorifics and modal particles rather than on indirectness for expressing politeness. Therefore, speakers of Vietnamese as second language should be made aware of these politeness strategies so that they can make informed pragmatic decisions that do not break down communication while allowing them to maintain their cultural identities. The present study also adds further evidence to support Vu's claim that besides 'strategic politeness' that allows the speaker's intention to influence his or 
her linguistic behavior, 'respectful politeness' that requires the speaker to conform to socially accepted behaviors is another important feature characteristic of Vietnamese pragmatics. Pragmatic instruction, therefore, may focus on this culture-specific aspect of politeness, which may pose challenges to learners, particularly those from an English speaking background.

The first limitation of the present study lies in the use of elicited rather than naturally occurring data. Although role-play data involve extended and real time discourse and therefore, share many similarities with authentic discourse, they are not shortcoming-free. Role plays are pretence without real consequences for the participants and hence, their use must be cautioned in research. Future research making use of authentic discourse, therefore, would be desirable. This is because recently there has been a call for a move away from speech act coding of elicted data and greater reliance on authentic data and conversation analytic method of data analysis (Kasper 2006).

Another limitation includes a small, non-randomized, gender-biased and homogeneous sample size. To enhance the representativeness of the data, future research should recruit a larger gender-mixed group of participants from various socioeconomic backgrounds and age groups who speak different dialects of Vietnamese. Future research may also benefit from an analysis of gender and age effects on requestive behaviour in different Vietnamese dialects.

\section{Appendix A \\ ROLE PLAY CARDS FOR PARTICIPANTS \\ English translation}

\section{INSTRUCTION SHEET FOR PARTICIPANTS}

You will talk with the researcher in the following role-play scenarios. Use Vietnamese when you talk. Take some minutes to read the descriptions of the scenarios. There are two questions for each scenario that you need to answer before role-playing. Try to imagine yourself in the scenarios and respond to them as you would do in the real life.

It is important that you understand these scenarios completely, so before you start you are encouraged to ask questions if you find something you do not understand.

Your role-play conversations will be tape-recorded with your consent. Thank you for your cooperation.

\section{Scenario 1:}

You are typing up a three-page essay for your lecturer. It is due today. You have just finished the first paragraph when suddenly, your computer stops working. You see your flatmate chatting online at the moment. You two are good friends. So you ask her to lend you her computer so that you can finish your work. It is important that you get her to agree to lend you the computer.

Question 1: Can you imagine yourself in this situation?

Circle the score that best fits you.

$\begin{array}{ccccl}1 & 2 & 3 & 4 & 5 \\ \text { Definitely NO } & & & & \text { Definitely YES }\end{array}$




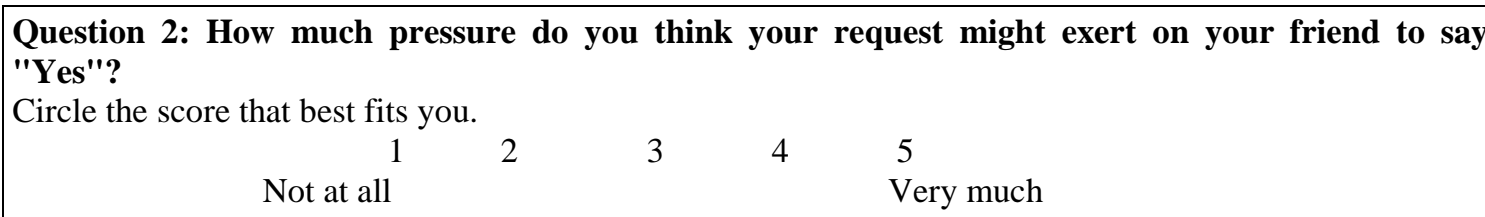

Now start your role-play in Vietnamese. The researcher will be your flatmate.

Scenario 2:

You were sick and missed an important class last week. Now you are reading the class materials but it is difficult to understand them by yourself. Luckily, your friend attended the class and took careful notes. You two are good friends. So you believe she would not mind lending you her notes. You approach your friend and ask for the favour. It is important that you get her to agree to lend you the notes.

Question 1: Can you imagine yourself in this situation?

Circle the score that best fits you.

$\begin{array}{ccccc}1 & 2 & 3 & 4 & 5 \\ \text { Definitely NO } & & & & \text { Definitely YES }\end{array}$

Question 2: How much pressure do you think your request might exert on your friend to say "Yes"?

Circle the score that best fits you.

$\begin{array}{ccccc}1 & 2 & 3 & 4 & 5 \\ \text { Not at all } & & & & \text { Very much }\end{array}$

Now start your role-play in Vietnamese. The researcher will be your flatmate.

Scenario 3:

You have to return a book to the library by today. You were still using it until last night. You go to school only on the day you have a class because you live quite far. Today you do not have a class. Your flatmate is having a class this morning, so you ask her to drop the book for you. It is important that you get her to agree to help you. You two are good friends.

Question 1: Can you imagine yourself in this situation?

Circle the score that best fits you.

$\begin{array}{ccccc}1 & 2 & 3 & 4 & 5 \\ \text { Definitely NO } & & & & \text { Definitely YES }\end{array}$

Question 2: How much pressure do you think your request might exert on your friend to say "Yes"?

Circle the score that best fits you.

$\begin{array}{ccccc}1 & 2 & 3 & 4 & 5 \\ \text { Not at all } & & & & \text { Very much }\end{array}$

Now start your role-play in Vietnamese. The researcher will be your flatmate.

Scenario 4:

You have just learned about a scholarship, which you would like to apply for. You need a reference letter from your lecturer urgently because the application closes in a few days' time. There is a lecturer who has been teaching you for quite a few semesters and you have always been one of the best students in her class. You know she is very busy but believe she would be supportive enough to write you a reference letter. So after class you approach her and ask for the favour. You really want the scholarship so it is important that you get her to agree to help you.

Question 1: Can you imagine yourself in this situation?

Circle the score that best fits you. 


$\begin{array}{ccccl}1 & 2 & 3 & 4 & 5 \\ \text { Definitely NO } & & & & \text { Definitely YES }\end{array}$

Question 2: How much pressure do you think your request might exert on your friend to say "Yes"?

Circle the score that best fits you.

$\begin{array}{ccccc}1 & 2 & 3 & 4 & 5 \\ \text { Not at all } & & & & \text { Very much }\end{array}$

Now start your role-play in Vietnamese. The researcher will be your flatmate.

Scenario 5

You are writing your thesis. You are having a meeting with your supervisor today and you are supposed to give her a chapter draft. However, last week you were sick and not able to complete the chapter. You would need some more time. At the meeting you ask your supervisor for an extension. You want to have her feedback as soon as possible so you will try to finish the chapter in the soonest time possible. It is important that you get her to agree to give you the extension.

Question 1: Can you imagine yourself in this situation?

Circle the score that best fits you.

$\begin{array}{ccccc}1 & 2 & 3 & 4 & 5 \\ \text { Definitely NO } & & & & \text { Definitely YES }\end{array}$

Question 2: How much pressure do you think your request might exert on your friend to say "Yes"?

Circle the score that best fits you.

$\begin{array}{ccccc}1 & 2 & 3 & 4 & 5 \\ \text { Not at all } & & & & \text { Very much }\end{array}$

Now start your role-play in Vietnamese. The researcher will be your flatmate.

Scenario 6:

Today is Monday. You have had an appointment with your supervisor at 10:30 a.m. Friday this week. You want to show her your revised thesis. However, another lecturer wants to make up for his missed class last week and unluckily, 10-12 a.m. this Friday is the only time slot that is suited to most students in the class. You do not want to miss this class because it is going to cover a difficult and important topic. So you drop in your supervisor's office and ask if she can move the appointment to another date or time. It is important that you get your supervisor to agree to see you as soon as she can because the deadline for submission of your thesis is coming in a few weeks' time.

Question 1: Can you imagine yourself in this situation?

Circle the score that best fits you.

$\begin{array}{ccccc}1 & 2 & 3 & 4 & 5 \\ \text { Definitely NO } & & & & \text { Definitely YES }\end{array}$

Question 2: How much pressure do you think your request might exert on your friend to say "Yes"?

Circle the score that best fits you.

$\begin{array}{ccccc}1 & 2 & 3 & 4 & 5 \\ \text { Not at all } & & & & \text { Very much }\end{array}$

Now start your role-play in Vietnamese. The researcher will be your flatmate. 


\title{
Appendix B: English translation
}

\section{ROLE PLAY CARDS FOR INTERLOCUTOR}

\section{INSTRUCTION SHEET FOR INTERLOCUTOR:}

You will converse in Vietnamese with each student in six role-play situations, which are described in each card. Read the descriptions of the situations carefully and act accordingly.

It is important that you understand the situations completely; therefore, you are encouraged to ask questions if you find something you do not understand.

Your conversations with the students will be tape-recorded with your consent for the purpose of the study.

Thank you for your cooperation.

\begin{abstract}
Scenario 1:
Your flatmate is typing a three-page essay for her/ his lecturer. Suddenly her/ his computer stops working and s/he asks you to lend her/ him your computer. You are chatting online with your boyfriend, who is in another town at the moment. Today is your boyfriend's birthday. But if it is urgent and your friend is not going to use the computer for an hour, you are willing to lend it to her/ him. You two are good friends.
\end{abstract}

Scenario 2:

Your friend was sick and missed an important class last week. You attended the class and took careful notes. So s/he approaches you and asks if you mind lending her/ him your notes. You are working on your assignments right now and need the notes at hand. However, if s/he can make a quick photocopy and give you back within an hour, you are willing to lend her/ him the notes. You two are good friends.

\section{Scenario 3:}

Your flatmate has a book to return to the library. You are going to school today. So your flatmate asks you to drop the book for her. You are having a class from 9am to $12 \mathrm{pm}$ in a building quite far from the library. After that you have a part-time job on another campus. Your job starts at 12:30pm, so you will be in a hurry. But if the book is due today, you can go to school some minutes earlier and drop the book for your flatmate first thing in the morning.

\section{Scenario 4:}

You are a university lecturer. A student in your class is applying for a scholarship and wants you to write her/ him a reference letter. You have been teaching this student for quite a few semesters and know s/he is one of your best students. You would be happy to write her/ him a reference letter but you are having some deadlines at the moment. So if it is not urgent, you will write it next week.

\section{Scenario 5:}

You are a university lecturer and supervising a student's thesis. The student that you are supervising is supposed to submit a chapter draft to you when you two have a meeting today. However, s/he was sick and not able to complete it. At the meeting s/he asks for an extension. You can give her/ him as much time as s/he needs. However, you are taking a sabbatical leave in two weeks' time. If s/he can give you the chapter within the next week, you can read it and give your comments before you go. If not, it may take a longer while for you to get back to her/ him because you have other commitments.

Scenario 6: 
You are a university lecturer. You have an appointment with your student at 10:30 a.m. Friday this week. $\mathrm{S} /$ he wants to show you her/ his revised thesis. You are her/ his supervisor. However, today s/he drops in your office and asks if you can move the appointment to another date or time because s/he has an urgent class. You are fully booked until two weeks after but if the student can come after your office hour tomorrow, you are willing to see her/ him then.

\section{References}

Al-Gahtani, Sadd, and Carsten Röver (2012) Proficiency and sequential organization of L2 requests. Applied Linguistics 33: 42-65.

Arundale, Robert (2006) Face as relational and interactional: A communication framework for research on face, facework, and politeness. Journal of Politeness Research 2: 193-216.

Barron, Anne (2008) Contrasting requests in Inner Circle Englishes. A study in variational pragmatics. In M. Puetz, and J. Neff van Aertselaer (eds.), Developing contrastive pragmatics: Interlanguage and crosscultural perspectives. Berlin: Mouton de Gruyter, pp.355-402.

Biesenbach-Lucas, Sigrun (2007) Students writing emails to faculty: An examination of e-politeness among native and non-native speakers of English. Language learning and Technology 11: 59-81.

Billmyer, Kristine, and Manka Varghese (2000) Investigating instrument-based pragmatic variability: Effects of enhancing discourse completion tests. Applied Linguistics 21: 517-552.

Blum-Kulka, Shoshana (1987) Indirectness and politeness in requests: Same or different? Journal of Pragmatics 11: 131-146.

Blum-Kulka, Shoshana, and Elite Olshtain (1984) Requests and apologies: A cross-cultural study of speech act realisation patterns (CCSARP). Applied Linguistics 5: 196-213.

Blum-Kulka, Shoshana, Juliane House, and Gabriele Kasper (1989) Cross-cultural pragmatics: Requests and apologies. Norwood, New Jersey: Ablex.

Bonikowska, Malgorzata (1988) The choice of opting out. Applied Linguistics 9: 169- 181.

Brown, Penelope, and Stephen Levinson (1978) Universals in language usage: Politeness phenomena. In E. Goody (ed.), Questions and politeness. Strategies in social interaction. Cambridge: Cambridge University Press, pp. 56-289.

Brown, Penelope, and Stephen Levinson (1987) Politeness: Some universals in language usage. Cambridge: Cambridge University Press.

Byon, Andrew Sangpil (2006) The role of linguistic indirectness and honorifics in achieving linguistic politeness in Korean requests. Journal of Politeness Research 2: 247-276.

Chen, Chi-Fen Emily (2006) The development of e-mail literacy: From writing to peers to writing to authority figures. Language Learning \& Technology 10: 35-55.

Chew, Grace (2011) Politeness in Vietnamese. In D. Kádár, and S. Mills (eds.), Politeness in East Asia. New York: Cambridge University Press, pp. 208-225. 
Cohen, Andrew, and Rachel Shively (2007) Acquisition of requests and apologies in Spanish and French: Impact of study abroad and strategy building intervention. The Modern Language Journal 91: 189-212.

Félix-Brasdefer, César (2007) Pragmatic development in the Spanish as a FL classroom: A crosssectional study of learner requests. Intercultural Pragmatics 4: 253-286.

Grice, Paul (1975) Logic and conversation. In P. Cole, and J. Morgan (eds.), Syntax and semantics Vol. 3 : Speech Acts. New York: Academic Press, pp. 41-58.

Gu, Yueguo (1990) Politeness phenomena in modern Chinese. Pragmatics 14: 237-257.

Hassall, Timothy (1999) Request strategies in Indonesian. Pragmatics 9: 585-606.

Hassall, Timothy (2003) Requests by Australian learners of Indonesian. Journal of Pragmatics 35: 19031928.

Hendriks, Berna (2008) Dutch English requests: A study of request performance by Dutch learners of English. In M. Puetz, and J. Neff van Aertselaer (eds.), Developing contrastive pragmatics: Interlanguage and cross-cultural perspectives. Berlin: Mouton de Gruyter, pp. 335-354.

Hill, Beverly, Sachiko Ide, Shoko Ikuta, Akiko Kawasaki, and Tsunao Ogino (1986) Universals of linguistic politeness: Quantitative evidence from Japanese and American English. Journal of Pragmatics 10: $347-471$.

House, Juliane, and Gabriele Kasper (1987) Interlanguage pragmatics: Requesting in a foreign language. In W. Lörscher, and R. Schulze (eds.), Perspectives on language in performance. Tübingen: Narr, pp. 1250-1288.

Ide, Sachiko (1989) Formal forms and discernment: Two neglected aspects of universals of linguistic politeness. Multilingua 8: 223-248.

Kasper, Gabriele (1981) Pragmatische Aspekte in der Interimsprache. Tubingen: Narr.

Kasper, Gabriele (2006) Speech acts in interaction: Towards discursive pragmatics. In K. Bardovi-Harlig, J.C. Felix-Brasdefer, and A. Omar (eds.), Pragmatics and Language Learning (vol. 11). Honolulu, HI: National Foreign Language Resource Center, University of Hawaii at Manoa, pp. 281-314.

Kasper, Gabriele (2008) Data collection in pragmatic research. In H. Spencer-Oatey (ed.), Culturally Speaking: Culture, Communication and Politeness Theory ( $2^{\text {nd }}$ revised edition). New York: Continuum, pp. 279-303.

Kasper, Gabriele, and Kenneth Rose (2002) Pragmatic development in a second language. Oxford: Blackwell.

Leech, Geoffrey (1983) Principles of Pragmatics. New York: Longman.

Lee-Wong, Song Mei (1994) Imperatives in requests: Direct or impolite - Observations from Chinese. Pragmatics 4: 491-515.

Matsumoto, Yoshiko (1988) Reexamination of the universality of face. Journal of Pragmatics 12: 403426.

Mao, Luming (1994) Beyond politeness theory: 'Face' revisited and renewed. Journal of Pragmatics 21: 451-486.

Mills, Margaret (1992) Conventionalized politeness in Russian requests: A pragmatic view of indirectness. Russian Linguistics 16: 65-78. 
Nguyen, Thi Thuy Minh (2008) Modifying L2 criticisms: How learners do it? Journal of Pragmatics 40: 768-791.

Nguyen, Thi Thuy Minh (2011) Learning to communicate in a globalized world: To what extent do school textbooks facilitate the development of intercultural pragmatic competence? RELC Journal 42: 17-30.

Ogiermann, Eva (2009) Politeness and indirectness across cultures: A comparison of English, German, Polish and Russian requests. Journal of Politeness Research 5: 189-216.

Okada, Ysuke (2010) Role play in oral proficiency interviews: Interactive footing and interactional competencies. Journal of Pragmatics 42: 1647-1668.

Otcu, Bahae, and Deniz Zeyrek (2006) Requesting in L2: Pragmatic development of Turkish learners of English. In Series A: General \& Theoretical Papers, LAUD 2006. Essen: Universitat Duisburg-Essen.

Otcu, Bahae, and Deniz Zeyrek (2008) Development of requests: A study on Turkish learners of English. In M. Puetz, and J. Neff van Aertselaer (eds.), Developing contrastive pragmatics: Interlanguage and crosscultural perspectives Berlin: Mouton de Gruyter, pp. 265-300.

Pham, Thi hong Nhung (2008) Vietnamese politeness in Vietnamese-Anglo culturalinteractions. Unpublished Ph.D. thesis. Queensland: The University of Queensland.

Pham, Thi Thanh (1995) Nghi thức lời nói tiếng Việt hiện đại qua các phát ngôn chào, cảm ơn, xin lỗi [Rituals in modern Vietnamese speech acts: Greetings, thanking, apologizing]. Unpublished Ph.D. thesis. Hà Nội: Đại học Khoa học Xã hội và Nhân văn.

Pham, Van Bich (1999) The Vietnamese family in change. Richmond: Curzon Press.

Rue, Yongju, and Grace Zhang (2008) Request strategies: A comparative study in Mandarin Chinese and Korean. Amsterdam: John Benjamins Publishing Company.

Schauer, Gilla (2007) Finding the right words in the study abroad context: The development of German learners' use of external modifiers in English. Intercultural Pragmatics 4: 193-220.

Schauer, Gilla (2008) Getting better in getting what you want: Language learners' pragmatic development in requests during study abroad sojourns. In M. Puetz, and J. Neff van Aertselaer (eds.), Developing contrastive pragmatics: Interlanguage and cross-cultural perspectives. Berlin: Mouton de Gruyter, pp.399-426.

Schauer, Gilla (2009) Interlanguage pragmatic development. The study abroad context. London: Continuum.

Searle, John (1969) Speech acts - An essay in the philosophy of language. London: Cambridge University Press.

Searle, John (1975) Indirect speech acts. In P. Cole, and J. Morgan (eds.), Syntax and semantics 3: Speech acts. New York: Academic Press.

Shively, Rachel (2011) L2 pragmatic development in study abroad: A longitudinal study of Spanish service encounters. Journal of Pragmatics 43: 1818-1835.

Takahashi, Satomi (1996) Pragmatic transferability. Studies in Second Language Acquisition 18: 189-223.

Taleghani-Nikazm, Carmen (2005) Contingent requests: Their sequential organization and turn shape. Research on Language and Social Interaction 38: 159-177. 
Taleghani-Nikazm, Carmen (2006) Request Sequences: The Intersection of Grammar, Interaction and Social Context. Amsterdam: John Benjamins Publishing Company.

Taleghani-Nikazm, Carmen, and Thorsten Huth (2010) L2 requests: Preference structure in talk-ininteraction. Multilingua 29: 185-202.

Tran, Ngoc Them (1995) Co sở văn hóa Việt Nam. TP Hồ Chí Minh: Trường ĐH Tổng hợp TP Hồ Chí Minh.

Tran, Ngoc Them (2001) Tìm về bản sắc văn hóa Việt Nam. TP Hồ Chí Minh: NXB TP Hồ Chí Minh.

Trosborg, Anna (1995) Interlanguage Pragmatics: Requests, Complaints, and Apologies. Berlin: Mouton de Gruyter.

Upadhyay, Shiv (2003) Nepali requestive acts: Linguistic indirectness and politeness reconsidered. Journal of Pragmatics 35: 1651-1677.

Vu, Thi Thanh Huong (1997) Politeness in modern Vietnamese. A sociolinguistic study of a Hanoi speech community. Unpublished doctoral thesis. Toronto: University of Toronto.

Vu, Thi Thanh Huong (1999) Gián tiếp và lịch sự trong lời cầu khẩn tiếng Việt. Ngôn ngũ 1: 34-43.

Wierzbicka, Anna (1985) Different cultures, different languages, different speech acts. Polish vs. English. Journal of Pragmatics 9: 145-178.

Woodfield, Helen (2008) Interlanguage requests: A contrastive study. In M. Puetz, and J. Neff van Aertselaer (eds.), Developing contrastive pragmatics: Interlanguage and cross-cultural perspectives . Berlin: Mouton de Gruyter, pp. 231-264.

Yu, Kyong-Ae (2011) Culture-specific concepts of politeness: Indirectness and politeness in English, Hebrew and Korean requests. Intercultural Pragmatics 8.3: 385-409.

NGUYEN THI THUY MINH is an assistant professor at National Institute of Education, Nanyang Technological University, Singapore. Her research interests are in pragmatics and language learning, language pedagogy and language teacher education. She has published in Journal of Pragmatics, Intercultural Pragmatics, Language Awareness, Multilingua, RELC Journal of Language Teaching and Research and elsewhere. Her recent book is titled Learning to give and respond to peer-feedback in the L2: A case of EFL criticisms and responses to criticisms (Lincom Europa, Germany) and recent book chapters appear in TESOL Classroom Practices series (published by TESOL Inc, VA), Pragmatics and Language Learning Vol 13 and Pragmatics of Vietnamese as a native and target language (both are published by National Foreign Language Resource Center, University of Hawai'i).

Address: National Institute of Education, Nanyang Technological University, Singapore

Corresponding address: 1 Nanyang Walk, Singapore 637616; e-mail: thithuyminh.nguyen@nie.edu.sg; thuyminhnguyen@gmail.com 


\section{Thi Thuy Minh Nguyen and Gia Anh Le Ho}

HO GIA ANH LE teaches Vietnamese at the National University of Singapore (NUS). She has received two Teaching Excellence Awards from the Centre for Language Studies, NUS. Her areas of research include the use of blogging and social media in pedagogy, second language curriculum development, Vietnamese pragmatics, second language acquisition, and the characteristics of advanced language learners. Her forthcoming publication entitled "Apologizing in Vietnamese as a native and target language" will appear in the edited volume Pragmatics of Vietnamese as a native and target language, to be published by National Foreign Language Resource Center, University of Hawai'i.

Address: National University of Singapore, Centre for Language Studies, Block AS4 \# 05-17, 9 Arts Link, Singapore, 117570; e-mail: clshgal@ nus.edu.sg 